\title{
Synthesis and Usage of Active Modified Zn-Zeolite as an Antibacterial Agent
}

\author{
Candan $\mathrm{Akca}^{1^{*}}$, Ayşegül Ekmekçi Körlü̈${ }^{2}$, Mustafa Ateş ${ }^{3}$ \\ ${ }^{1}$ Salihli Vocational School, Manisa Celal Bayar University, Manisa, Turkey \\ ${ }^{2}$ Department of Textile Engineering, Faculty of Engineering, Ege University, İzmir, Turkey \\ ${ }^{3}$ Department of Biology, Faculty of Science, Ege University, İzmir, Turkey \\ *candanakca@yahoo.com \\ Received: 09 January 2018 \\ Accepted: 11 July 2018 \\ DOI: $10.18466 /$ cbayarfbe. 376580
}

\begin{abstract}
Natural zeolites are one of the most examined natural minerals. By means of new studies conducted on zeolites, new areas of usage are being discovered day by day. It is possible to produce modified zeolites that having many variable functions by using the ion exchange capability of zeolite. In this study $100 \%$ cotton fabrics was used in the trials. The natural zeolite, used in the trials, was provided from Enli Madencilik A.Ş. and originated from the Manisa-Gördes region. The manufacturing of Zn-Zeolite was performed. And then the $\mathrm{Zn}$-Zeolite were applied to cotton fabrics. The characteristics of the cotton fabrics treated with zinc-loaded antibacterial zeolite are analyzed in this article.
\end{abstract}

Key Words: Zeolite, zinc, antibacterial, textile, ICP-MS, whiteness degree.

\section{Introduction}

Zeolites having wide areas of application in commercial terms and being the main subject of many research, were discovered by Cronstedt who is a Swedish mineralogist in 1756. Cronstedt called this mineral "zeolite" which means "zeo" (boiling) and "lithos" (stone) in Greek as he noticed that the stone produced large amounts of steam when it was heated [1-3]. What zeolites can be used for was discovered with the studies conducted by the chemists named Weigel and Steinhoff approximately 200 years later. It was observed that the zeolites adsorb small organic molecules; however they do not let big molecules enter into zeolite structure. Due to their molecular sieving feature of zeolites, Mc Bain called them "molecular sieves" [1-3]. On the other hand, Barrer discovered their micro porous structures and ion exchange features [2]. Zeolite is a mineral group with hydrated alumina silicate composition including alkali and alkaline-earth cations chemically in its framework silicate structure.

There are channels and gaps, the sizes of which differentiate between 3-10 angstrom, within their structures. The main units within the zeolite structure are $\mathrm{SiO}_{4}$ and $\mathrm{AlO}_{4}$ tetrahedra where $\mathrm{Si}$ and $\mathrm{Al}$, which can be replaced by $\mathrm{Si}$, are located in the center [3].

The order composed by tetrahedra in zeolites, cations and water molecules form a general zeolite chemistry as "(Na, K, Li, $\mathrm{Ca}, \mathrm{Mg}, \mathrm{Fe}, \mathrm{Ba}, \mathrm{Sr})\left(\mathrm{Al} \mathrm{Si}_{2-5}\right)_{6-12} \mathrm{O}_{12-24}$. $\mathrm{nH}_{2} \mathrm{O}$ ". The ideal zeolite chemistry hosts as many cations as $\mathrm{Al}$ that replaces $\mathrm{Si}$. Cations within the pores of zeolites are dynamic and they can be replaced by the cations in the solutions when it contacts with the solutions including other cations [1, 4-6]. The ion exchange is observed in the zeolites takes place in accordance with the reaction given below:

$$
\mathrm{A}^{+}+\mathrm{BZ} \rightleftarrows \mathrm{B}^{+}+\mathrm{AZ}
$$

In this reaction, a solution including $\mathrm{A}$ ions is contacted with a zeolite carrying $\mathrm{B}$ ions, and the $\mathrm{A}$ ions in the solution are replaced by the B ions in the zeolite [1].

There are some studies regarding the use of zeolites functionalized through ion exchange in the textile and leather industry. Japanese researchers produced antibacterial artificial leather using antibacterial zeolite [7]. Yoshikazu and Tetsuya produced antibacterial recycled polypropylene [8]. Taisheng, Wang and Cao produced antibacterial shoe lining [9]. Ruiwen, Yue and Shao succeeded in producing antibacterial viscose fiber [10]. Bozoğlu produced antibacterial diapers with silver and zinc ion exchanged zeolite. He reported that he achieved good results against E.coli; however he experienced some problems regarding color change [1]. In this study, some features such as antibacterial efficiency, washing durability, change of whiteness degree and air permeability by applying the zinc loaded zeolites on the cotton fabric at different concentrations were investigated. The study will contribute to the literature with respect to the medical areas of use of cotton fabrics treated with zinc-loaded zeolite. 


\section{Materials and Methods}

The fabric used in the trials was a $100 \%$ cotton, desized, scoured and bleached woven textile fabric. The natural zeolite used in the trials was provided from Enli Madencilik A.Ş. and originated from the Manisa Gördes region; its grain size is $30 \mu \mathrm{m}$.

By loading the natural zeolite with $\mathrm{Na}^{+}, \mathrm{Na}$-zeolite was obtained. $\mathrm{NaCl}$ was used as the $\mathrm{Na}^{+}$source. The natural zeolite was treated in $1 \mathrm{~N} \mathrm{NaCI}$ solution with a mixing speed of $500 \mathrm{rpm}$ at $60{ }^{\circ} \mathrm{C}$ in a glass beaker for 1 week during the process. NaCI solution was replaced each day. After this process, the sample was thoroughly washed with purified water for several times and dried at $110^{\circ} \mathrm{C}$ in drying oven. The main purpose of this treatment is purifying the natural zeolite from other elements in its structure and increasing its cation binding capacity.

The Na-zeolite obtained was treated in the following solution $(0,1 \mathrm{M}$ and $0,01 \mathrm{M}) \mathrm{Zn}\left(\mathrm{NO}_{3}\right)_{2} \cdot 6 \mathrm{H}_{2} \mathrm{O}$ at two different concentration levels in a magnetic mixer for two days. After the modification treatment, the modified zeolites were washed with purified water for five times and dried at $110^{\circ} \mathrm{C}$ in the drying oven; in this way NaZn-zeolite was acquired [11,12]. Na-Zn-zeolite was applied on the cotton fabric via a acrylic based binder at three different concentration levels $(5 \mathrm{~g} / 1$ for $0,1 \mathrm{M} ; 5$ $\mathrm{g} / \mathrm{l}, 1.25 \mathrm{~g} / \mathrm{l}, 0,3125 \mathrm{~g} / \mathrm{l}$ for $1.25 \mathrm{~g} / \mathrm{l}, 0,3125 \mathrm{~g} / \mathrm{l}$ 0,01 M). Padding recipe is a modified pigment dyeing recipe. The pick-up values were approximately $80 \%$.

The zinc ion amount on the cotton fabric was measured with ICP-MS (Inductively coupled plasma mass spectrometry) (Agilent ICPMS 7500ce). Before the measurement process was performed with ICP-MS, the cotton fabrics, treated with $\mathrm{Na}-\mathrm{Zn}$-zeolite, were carbonized within acid solution $\left(\mathrm{HNO}_{3}\right.$ and $\left.\mathrm{HCl}\right)$ in the microwave oven (MARS Microwave Accelerated Reaction System MARS 5 Version 194AO2). Thereafter, elemental analysis was carried out. The imaging of the surfaces of the fabrics was performed with SEM (FEI Quanta 250 FEG) device. The antibacterial efficiency tests were conducted in accordance with AATCC 100 [13]. Washing durability tests were performed following the 5th, 10th, 15th, and 20th washing processes. The washing processes took place in the lab-type dyeing machine using ECE (SDL Atlas reference detergent B) at $60{ }^{\circ} \mathrm{C}$. Wascator or household washing machine was not used during the washing process due to the contamination risk. The whiteness degrees of the fabrics were measured with spectrophotometer (Minolta CM-3600 d) according to the Stensby Formula. The air permeability values of the fabrics were measured with air permeability measuring device (Textest Instruments FX3300).

\section{Results and Discussion}

\subsection{The Results of ICP-MS and SEM}

0,1 M and 0,01 M Zn-Na-Zeolites were applied on the cotton fabrics at three amounts $(5 \mathrm{~g} / 1,1,25 \mathrm{~g} / 1,0,3125$ $\mathrm{g} / \mathrm{l})$.

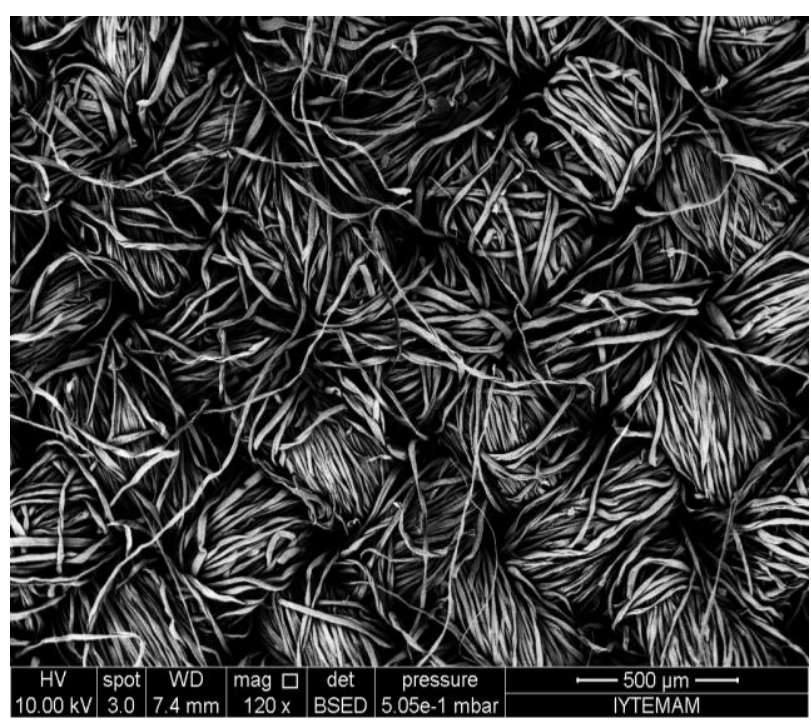

Figure 1. Greige cotton fabric $(\times 120)$.

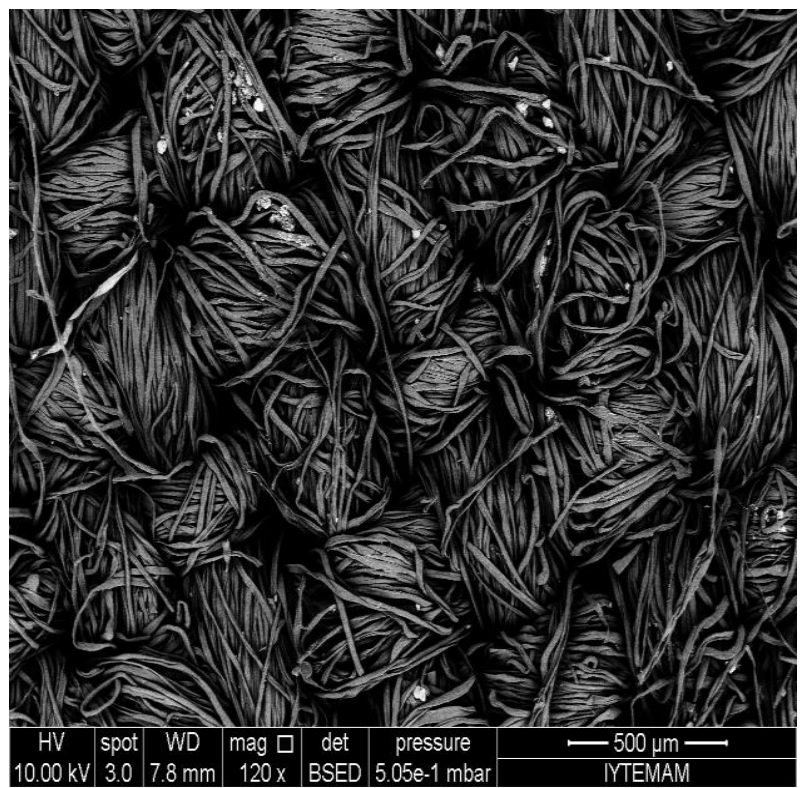

Figure $2.5 \mathrm{~g} / \mathrm{l}$ of $0,1 \mathrm{M} \mathrm{Zn}\left(\mathrm{NO}_{3}\right)_{2} \cdot 6 \mathrm{H}_{2} \mathrm{O}$ zeolite applied to cotton fabric $(\times 120)$. 


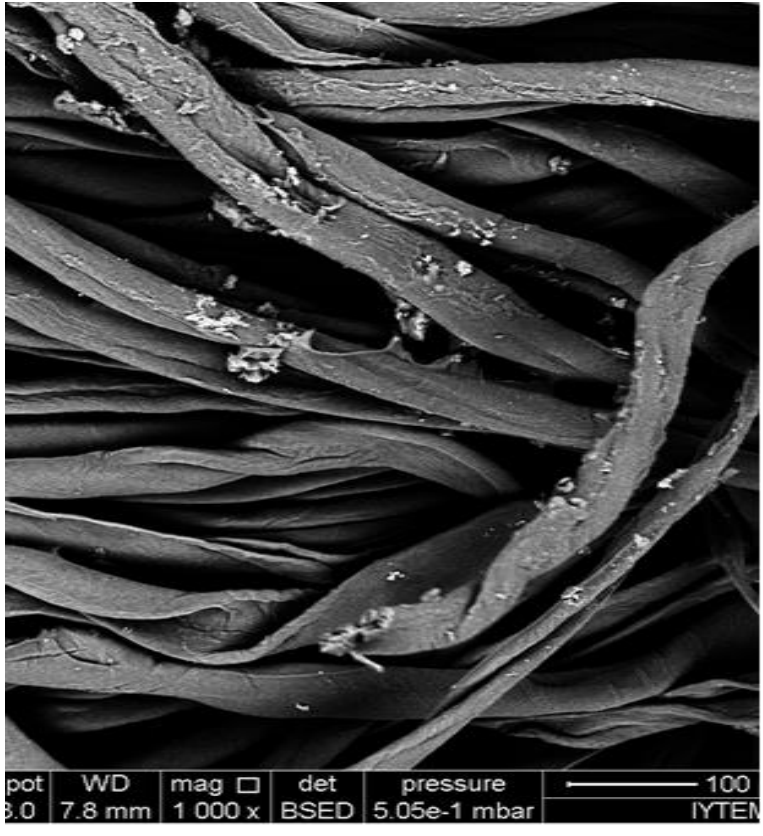

Figure 3. $5 \mathrm{~g} / \mathrm{l}$ of $0,01 \mathrm{M} \mathrm{Zn}\left(\mathrm{NO}_{3}\right)_{2} \cdot 6 \mathrm{H}_{2} \mathrm{O}$ zeolite applied to cotton fabric $(\times 1000)$.

The zinc ions can be clearly seen on the SEM images. As it can be seen on the figures numbered 2 and 3 , the zinc ion distribution on the fabric is not homogenous.

Table 1. Zinc Ion Content of the Cotton Fabrics (ICPMS).

\begin{tabular}{|c|c|c|c|c|}
\hline \multirow[t]{3}{*}{ Treated Cotton Fabrics } & \multirow{2}{*}{\multicolumn{2}{|c|}{$\begin{array}{c}\text { Zeolite Modified by 0,1M } \\
\mathrm{Zn}\left(\mathrm{NO}_{3}\right)_{2} 6 \mathrm{H}_{2} \mathrm{O} \\
\mathrm{Zn} \text { ion content }(\mathrm{mg}) / \text { Fabric } \\
\text { Quantity }(\mathbf{1 0 g})\end{array}$}} & \multirow{2}{*}{\multicolumn{2}{|c|}{$\begin{array}{c}\text { Zeolite Modified by } 0,01 \mathrm{M} \\
\mathrm{Zn}\left(\mathrm{NO}_{3}\right)_{2} 6 \mathrm{H}_{2} \mathrm{O} \\
\mathrm{Zn} \text { ion content }(\mathrm{mg}) / \text { Fabric } \\
\text { Quantity }(10 \mathrm{~g})\end{array}$}} \\
\hline & & & & \\
\hline & Unwash ed & $\begin{array}{l}20 \text { Times } \\
\text { Washed }\end{array}$ & Unwashed & $\begin{array}{l}20 \text { Times } \\
\text { Washed }\end{array}$ \\
\hline $\begin{array}{l}5 \mathrm{~g} / \mathrm{N} \text { Na-Zn-Zeolite } \\
\text { Applied Cotton Fabric }\end{array}$ & 1,018 & 0,438 & 0,472 & 0,297 \\
\hline $\begin{array}{l}\text { 1,25 Na-Zn-Zeoliteg/l } \\
\text { Applied Cotton Fabric }\end{array}$ & 0,403 & 0,296 & 0,311 & 0,289 \\
\hline $\begin{array}{l}\text { 0,3125 Na-Zn-Zeolite } \\
\text { g/l Applied Cotton } \\
\text { Fabric }\end{array}$ & 0,382 & 0,144 & 0,275 & 0,090 \\
\hline
\end{tabular}

After the $20^{\text {th }}$ washing process, these values went down to $0,438,0,296$ and $0,144 \mathrm{mg} / 10 \mathrm{~g}$ fabric, respectively. Also, when the table 3.1 is considered, it is seen that the $\mathrm{Zn}$ ion amounts on the fabrics (treated with $0,01 \mathrm{M} \mathrm{Zn-}$ Na-Zeolite) are as follows: 0,472, 0,311 and 0,275 $\mathrm{mg} / 10 \mathrm{~g}$ fabric, respectively. After the $20^{\text {th }}$ washing process, these values went down to 0,297, 0,289 and $0,090 \mathrm{mg} / 10 \mathrm{~g}$ fabric. These results indicate that the $\mathrm{Zn}$ ion amount on the fabric is directly proportional to $\mathrm{Zn}$ ion amount within the application solution; also that the $\mathrm{Zn}$ ion amount went down significantly after the washing processes. Both analysis values measured before and after the washing processes seem very consistent.

There is a significant difference between the $\mathrm{Zn}$ ion amounts on the cotton fabrics treated with $0,1 \mathrm{M}$ and $0,01 \mathrm{M} Z \mathrm{Zn}-\mathrm{Na}-\mathrm{Zeolites} \mathrm{equally.} \mathrm{For} \mathrm{instance,} \mathrm{while} \mathrm{the}$ $\mathrm{Zn}$ ion amount on the cotton fabric treated with $0,1 \mathrm{M} 5$ $\mathrm{g} / \mathrm{l}$ is $1,018 \mathrm{mg} / 10 \mathrm{~g}$ fabric, the $\mathrm{Zn}$ ion amount on the cotton fabric treated with $0,01 \mathrm{M} 5 \mathrm{~g} / \mathrm{l}$ is $0,472 \mathrm{mg} / 10 \mathrm{~g}$ fabric. It is seen that the analysis values are still very consistent considering other parallel fabrics on both charts.

\subsection{Antibacterial Efficiency and Washing Durability}

The antibacterial efficiency tests were performed in accordance with AATCC 100. Gram-positive $S$. aureus and gram-negative $K$. pneumoniae were used in the test. The incubation period took 6 hours. The washing durability tests were performed following 5., 10., 15., 20. washing processes.

When the table 1 is considered, it is seen that the $\mathrm{Zn}$ ion amounts on the fabrics (treated with $0,1 \mathrm{M} \mathrm{Zn}-\mathrm{Na}-$ Zeolite) are 1,018, 0,403 and 0,382 $\mathrm{mg} / 10 \mathrm{~g}$ fabric, respectively.

Table 2. Washing Durability and Antibacteraial Properties of the Treated Fabrics.

\begin{tabular}{|c|c|c|c|c|}
\hline \multicolumn{5}{|c|}{$\begin{array}{l}\text { Treated Cotton Fabric with } 5 \mathrm{~g} / \mathrm{l} \text { of Zeolite Modified by } \\
\qquad \mathrm{Zn}\left(\mathrm{NO}_{3}\right)_{2} .6 \mathrm{H}_{2} \mathrm{O}\end{array}$} \\
\hline \multirow{3}{*}{$\begin{array}{c}\text { Washing } \\
\text { Cycles }\end{array}$} & \multicolumn{2}{|c|}{$0,1 \mathrm{M}$} & \multicolumn{2}{|c|}{$0,01 \mathrm{M}$} \\
\hline & S.aureus & K.pneumoniae & S.aureus & K.pneumoniae \\
\hline & $\begin{array}{c}\text { Reduction } \\
(\%)\end{array}$ & Reduction (\%) & $\begin{array}{c}\text { Reduction } \\
(\%)\end{array}$ & Reduction (\% \\
\hline Unwashed & 83,31 & 79,52 & 80,15 & 54,445 \\
\hline 5 & 68,42 & 70,92 & 70,43 & 36,19 \\
\hline 10 & 53,115 & 56,235 & 45,68 & 5,04 \\
\hline 15 & 18,08 & 29,91 & 8,53 & 1,18 \\
\hline 20 & 7,28 & 3,665 & 4,58 & 0 \\
\hline
\end{tabular}

$(*)$ The antibacterial efficiency tests were repeated twice. The test result was assessed considering the total number of bacteria on the cotton fabric, which is $4.8 \mathrm{~cm}$ in diameter. At the beginning of the test, $10^{8} \mathrm{cfu} / \mathrm{ml}$ bacteria was cultivated on the cotton fabric, the diameter of which is $4,8 \mathrm{~cm}$.

As it is seen on the table 2, the antibacterial efficiency of the sample that was treated with $0,1 \mathrm{M} 5 \mathrm{~g} / \mathrm{l}$ and was not washed was around $83,31 \%$ against gram-positive $S$. aureus, and around $79,52 \%$ against gram-negative $K$. pneumoniae at the end of 6 hours; after the 20th washing process it was observed that these values went down to app.7,28\% against gram-positive $S$. aureus, and to app.3,665\% against gram-negative $K$. pneumoniae. Also, as it is seen on the table 3.2.1, the antibacterial efficiency of the sample that was treated with $0,01 \mathrm{M} 5 \mathrm{~g} / \mathrm{l}$ and was not washed was around $80,15 \%$ against gram-positive $S$. aureus, and around $54,445 \%$ against gram-negative $K$. pneumoniae at the end of 6 hours; after the 20th washing process it was observed that these values went down to app. 4,58\% against gram-positive S.aureus, and to $0 \%$ against gramnegative $K$. pneumoniae. As the number of washing 
process increased and the zinc amount decreased, the number of bacteria to survive increases. This is even seen more significantly in the gram-negative $K$. pneumoniae.

Table 3. Washing durability and Antibacteraial properties of the treated fabrics.

\begin{tabular}{|c|c|c|c|c|}
\hline \multicolumn{5}{|c|}{ Treated Cotton Fabric with 1,25 g// of Zeolite Modified by } \\
$\mathbf{Z n}\left(\mathbf{N O}_{\mathbf{3}} \mathbf{2}_{\mathbf{2}} \mathbf{. 6} \mathbf{H}_{\mathbf{2}} \mathbf{O}\right.$
\end{tabular}

(*)The antibacterial efficiency tests were repeated twice. The test result was assessed considering the total number of bacteria on the cotton fabric, which is $4.8 \mathrm{~cm}$ in diameter. At the beginning of the test, $10^{8} \mathrm{cfu} / \mathrm{ml}$ bacteria was cultivated on the cotton fabric, the diameter of which is $4,8 \mathrm{~cm}$.

As it is on the table 3, the antibacterial efficiency of the sample that was treated with $0,1 \mathrm{M} 1,25 \mathrm{~g} / \mathrm{l}$ and was not washed was around 40,45\% against gram-positive $S$. aureus, and around $35.57 \%$ against gram-negative $K$. pneumoniae at the end of 6 hours; after the 15th washing process it was observed that these values went down to app. $2,78 \%$ against gram-positive S. aureus, and to $0 \%$ against gram-negative $K$. pneumoniae. This indicates that the zinc ion amount on the fabric is not sufficient enough to create antibacterial effect. As it is seen on the chart 3.2.2, the antibacterial efficiency of

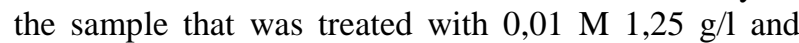
was not washed was around $17,44 \%$ against grampositive, and around $16.59 \%$ against gram-negative $K$. pneumoniae at the end of 6 hours; after the 10th washing process it was observed that these values went down to app. $2,7 \%$ against gram-positive $S$. aureus, and to $0 \%$ against gram-negative $K$. pneumoniae. As the number of washing processes increases, the zinc amount decreases, therefore the number of bacteria to survive increases.

Table 4. Washing durability and Antibacteraial properties of the treated fabrics.

\begin{tabular}{|c|c|c|c|c|}
\hline \multicolumn{5}{|c|}{$\begin{array}{l}\text { Treated Cotton Fabric with } 0,3125 \mathrm{~g} / \mathrm{l} \text { of Zeolite Modified by } \\
\qquad \mathrm{Zn}\left(\mathrm{NO}_{3}\right)_{2} \cdot 6 \mathrm{H}_{2} \mathrm{O}\end{array}$} \\
\hline \multirow{3}{*}{\begin{tabular}{c|} 
Washing \\
Cycles
\end{tabular}} & \multicolumn{2}{|c|}{$0,1 \mathrm{M}$} & \multicolumn{2}{|c|}{$\mathbf{0 , 0 1} \mathrm{M}$} \\
\hline & S.aureus & K.pneumoniae & S.aureus & K.pneumoniae \\
\hline & $\begin{array}{c}\text { Reduction } \\
(\%)\end{array}$ & Reduction (\%) & \begin{tabular}{|c|} 
Reduction \\
$(\%)$
\end{tabular} & Reduction (\%) \\
\hline Unwashed & 11,425 & 14,105 & 10 & 11,07 \\
\hline 5 & 8,01 & 2,985 & 6,975 & 0 \\
\hline 10 & 2,83 & 0 & 0 & 0 \\
\hline 15 & 0 & 0 & 0 & 0 \\
\hline 20 & 0 & 0 & 0 & 0 \\
\hline
\end{tabular}

(*) The antibacterial efficiency tests were repeated twice. The test result was assessed considering the total number of bacteria on the cotton fabric, which is $4.8 \mathrm{~cm}$ in diameter. At the beginning of the test, $10^{8} \mathrm{cfu} / \mathrm{ml}$ bacteria was cultivated on the fabric, the diameter of which is $4,8 \mathrm{~cm}$

As it is on the table 4, the antibacterial efficiency of the sample that was treated with $0,1 \mathrm{M} 0,3125 \mathrm{~g} / \mathrm{l}$ and was not washed was around $11,425 \%$ against gram-positive $S$. aureus, and around $14.105 \%$ against gram-negative $K$. pneumoniae at the end of 6 hours; after the 10th washing process it was observed that these values went down to app. $2,83 \%$ against gram-positive $S$. aureus, and to $0 \%$ against gram-negative $K$. pneumoniae. As it is seen on the chart 3.2.3, the antibacterial efficiency of the sample that was treated with $0,01 \mathrm{M} \mathrm{0,3125}$ and was not washed was around $10 \%$ against gram-positive, and around $11.07 \%$ against gram-negative $K$. pneumoniae at the end of 6 hours; after the 5th washing process it was observed that these values went down to app.6,975\% against gram-positive S.aureus, and to $0 \%$ against gramnegative $K$. pneumoniae. As the number of washing processes increases, the zinc amount decreases, therefore the number of bacteria to survive increases.

\subsection{Whiteness Degrees of The Fabrics}

The measurement regarding the whiteness degree was performed with spectrophotometer (Minolta CM-3600 d) in accordance with the Stensby formula for 3 months and the measurement processes were carried out at the same day as the application has taken place. The measurements were carried out with D65 illuminant and with an observation angle of $10^{\circ}$.

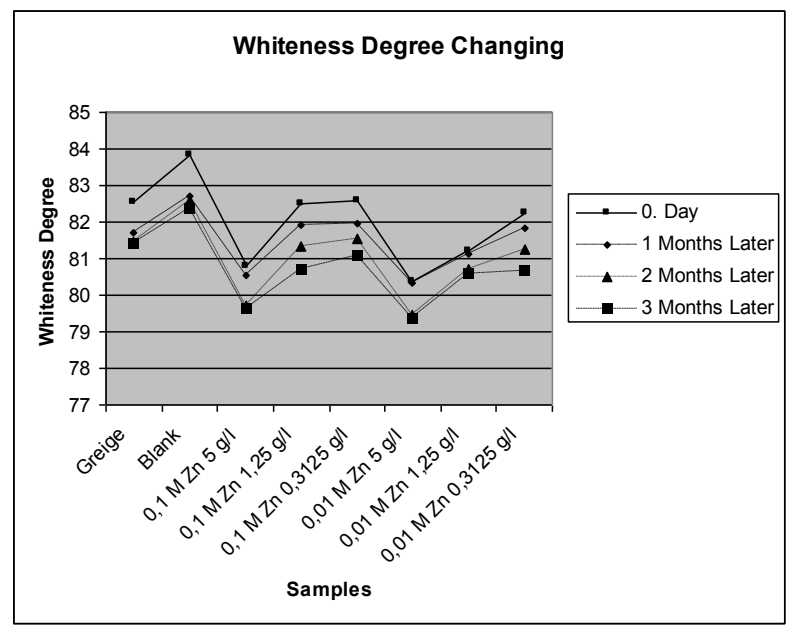

Figure 4. Whiteness degrees of cotton fabrics.

Analyzing the Figure 4, it is seen that the whiteness degree of the greige fabric is lower than the blank fabric's (blind fabric is a fabric, treated with an application solution including no $\mathrm{Zn}-\mathrm{Na}$-zeolite). The application solution was considered as the reason why the whiteness degree of the untreated fabric is lower than the blank fabric. Because of the thickener and the binder which were used in application solution are white. It is clearly seen that as the $\mathrm{Zn}$ ion and zeolite amount on the fabrics increased, the whiteness degree of the fabric decreased. The reason of this situation is the 
color of zeolite. The whiteness degree of the cotton fabrics treated with $\mathrm{Zn}-\mathrm{Na}-\mathrm{Zeolite}$ concentrated in $0,1 \mathrm{M}$ is lower than the cotton fabrics treated with $\mathrm{Zn}-\mathrm{Na}$ Zeolite concentrated in $0,01 \mathrm{M}$. This indicated the effect of the concentration.

\subsection{Air Permeability Values of the Fabrics}

The air permability test was performed in the air permability measuring device (Textest Instruments FX3300) in an experimental area of $5 \mathrm{~cm}^{2}$ under 100 Pascal pressure; and the test was repeated for 5 times.

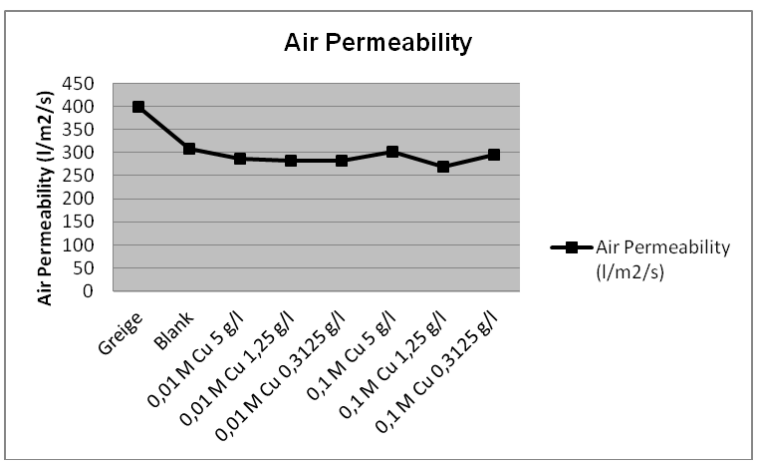

Figure 5. Air permeability values of $\mathrm{Zn}$-Na-zeolit applied cotton fabrics.

Analyzing the figure 5, it can be seen that the air permeability value of the blank fabric is lower than the greige fabric. It is because of the fabric pores shrink during the application. There isn't a significant difference between the air permeability of the fabrics treated with Zn-Na-zeolite in different quantities ( $5 \mathrm{~g} / \mathrm{l}$, $1,25 \mathrm{~g} / \mathrm{l}$ and $0,3125 \mathrm{~g} / 1$ both $0,1 \mathrm{M}$ and $0,01 \mathrm{M}$ ).

\section{Conclusion}

The natural zeolite was modified with $\mathrm{Zn}\left(\mathrm{NO}_{3}\right)_{2} \cdot 6 \mathrm{H}_{2} \mathrm{O}$ and $\mathrm{Zn}-\mathrm{Na}$-Zeolite was obtained in this study. The zinc ion amounts loaded to the natural zeolite were measured with ICP-MS. The obtained Zn-Na-zeolites obtained $(0,01 \mathrm{M}$ and $0,1 \mathrm{M})$ were applied on the cotton fabrics in three different quantities by means of an acrylic based binder and their antibacterial efficiencies along with their washing durability were tested against grampositive $S$. aureus and gram-negative $K$. pneumoniae. Depending on the modification concentration and the amounts applied on the fabric, different results regarding antibacterial efficiency and washing durability were acquired. However, as it is seen on the SEM images, the distribution of $\mathrm{Zn}-\mathrm{Na}-\mathrm{Zeolite}$ on the cotton fabric is not homogenous [14]. Bozoğlu has reported that modified zeolites has good antibacterial efficiencies against gram-negative $E$. coli but he reported some problems about color changing [1]. In our study there was a decline in the whiteness degree too but it was not a level to affect the usability of the fabric.

Analyzing the whiteness degrees, it is seen that as the zinc ion amount on the cotton fabric increases, the whiteness degree decreases. However, the decline in the whiteness degree is not a level to affect the usability of the fabric.

Analyzing the air permeability results, it is seen that the air permeability value of the blank fabric treated with application solution is significantly lower than the greige fabrics'. What caused this situation is subjected to the shrinking of the fabric pores during the application. There isn't a significant difference between the air permeability of the fabrics treated with $\mathrm{Zn}-\mathrm{Na}$ zeolite in different quantities $(5 \mathrm{~g} / 1,1,25 \mathrm{~g} / \mathrm{l}$ and 0,3125 $\mathrm{g} / \mathrm{l}$ both $0,1 \mathrm{M}$ and $0,01 \mathrm{M}$ ).

Following the silver, zinc is one of the commonly used metals in the textile production. The reason why zinc is preferred that much is the fact that zinc is mostly preferred in many topic antibiotics in the medical area. By using the zeolite as a zinc ion carrier, zinc ions are released into the environment slowly and at low concentrations, in this way both the toxic risk will not be a threat and the antibacterial efficiency will last longer [15]. In the wake of the study results, it is thought that the textile products including $\mathrm{Zn}-\mathrm{Na}$-zeolite can be used as wound dress.

\section{References}

1. Bozoğlu, A. Türkiye'de Çıkan Doğal Zeolitin Bebek Bezlerinde Antimikrobiyal Madde Olarak Kullanılması, İstanbul Teknik Üniversitesi, Yüksek Lisans Tezi, 2010.

2. Özaydın, S. Doğal Klinoptilolitlerin Türkiye'deki Kullanım Olanakları ve Gördes Klinoptilolitlerinin Isıl Özelliklerinin Belirlenmesi Üzerine Bir Araştırma, Ege Üniversitesi, Fen Bilimleri Enstitüsü, Doktora Tezi, 2005.

3. Devlet Planlama Teşkilatı Müsteşarlığı Dokuzuncu Kalkınma Planı (2007-2013) Madencilik Özel İhtisas Komisyonu Endüstriyel Hammaddeler Alt Komisyonu Genel Endüstri Mineralleri Zeolit Raporu, Ocak 2006.

4. http://www.gordeszeolite.com/zeolit-klinoptilolit. (Date of Access: 21th of September 2018).

5. http://www.chemistryexplained.com/Va-Z/Zeolites.html (Date of Access: 21th of September 2018).

6. https://www.explainthatstuff.com/zeolites.html (Date of Access: 21th of September 2018).

7. Shiyouji, H.; Toshiyuki, T. Antimikrobiyal Regenerated Leather Paper, Japan Patent, No: 11172581, 1999.

8. Yoshikazu, K.; Tetsuya, T.; Teruo, K. Influence of Thermal Hysteresis on Properties of Polypropylene Containing Antibacterial Agent, Japan Patent, No: CAN 139:180967 AN 2003:170856, 2002

9. Gong, T.; Wang, X.; Cao, Y. Application of Ag+-zeolite in the Antibacterial Finishing of Shoe Materials, CODEN: PKYGF6 ISSN: 1004-7964. Journal Written in Chinese. CAN 151:16362 AN 2009:212309 CAPLUS, 2008; 18(1), 44-47 pp.

10. Zhang, R.; Yue, G.; Shao, C.; Wang, H.; Xie, Y. Antibacterial Viscose Fiber Containing Silver-zeolite Antibacterial Agent and its Production, CODEN: CNXXEV CN1779004 A 20060531 Patent Written in Chinese. Application: CN 200410060290 20041126.Priority:CAN 145:64358 AN 2006:530678 CAPLUS, 2006. 
11. Top, A.; Ülkü, S. Silver, Zinc and Copper Exchange in a NaClinoptilolite and Resulting Effect on Antibacterial Activity, Applied Clay Science, 2004; 27, 13-19.

12. Ülkü, S. Antibacterial and Bactericidal Activity of Nitric Oxide-releasing Natural Zeolite, Applied Clay Science, 2010.

13. https://www.aatcc.org/test/methods/ (Date of Access: 21th of September 2018).

14. Scacchetti, A. Preparation and Characterization of Cotton Fabrics with Antimicrobial Properties through the Application of Chitosan/Silver-zeolite Film, 3th ICNF Conference, 2017.

15. Can, C. Zeolit Mineralinin Tekstil Terbiyesinde Kullanım Olanaklarının Araştırılması, Ege Üniversitesi Fen Bilimleri Enstitüsü, Doktora Tezi, 2012. 